\title{
The effect of electronic word of mouth communication on purchase intention and brand image: An applicant smartphone brands in North Cyprus
}

\author{
Muneer Alrwashdeh ${ }^{a^{*}}$, Okechukwu Lawrence Emeagwalia and Hasan Yousef Aljuhmani ${ }^{\mathrm{a}}$
}

${ }^{a}$ Girne American University, Marketing Management Department, via Mersin 10, North Cyprus, Turkey

${ }^{b}$ Girne American University, Business Management Department, via Mersin 10, North Cyprus, Turkey

\begin{tabular}{l}
\hline C H R O N I C L E \\
\hline Article history: \\
Received: January 02, 2019 \\
Received in revised format: Janu- \\
ary 17, 2019 \\
Accepted: January 17, 2019 \\
Available online: \\
January 20, 2019 \\
\hline Keywords: \\
Electronic word of mouth commu- \\
nication \\
Purchase intention \\
Brand image \\
Product type \\
Smartphone brands \\
\hline
\end{tabular}

A B S T R A C T

\begin{abstract}
This study aims to examine the effects of electronic word of mouth communication (eWOM) among consumers on purchase intention and brand image, specifically, Generation Y and Z groups in relation to smartphone brands. The study utilizes an empirical research model using data collected from 402 valid respondents among consumers who use smartphone brands in North Cyprus. The study uses structural equation modeling (SEM) to explore and conduct the analysis. The results confirm the significant effects of eWOM on purchase intention through brand image and the moderating role of product type among eWOM, purchase intentions and brand image. The study also recommends that firms and marketers must concentrate on online communication channels to affect consumers' intention toward purchasing brands and brand image. Moreover, the current study model suggests that future study can be extended in different context, countries (i.e. developed, emerging, developing), industries (i.e. banks, e-commerce, tourism) and different social media platforms sites (i.e. Facebook, Twitter).
\end{abstract}

C 2019 by the authors; licensee Growing Science, Canada

\section{Introduction}

Word of Mouth (WOM) has been one of the most important channels of communication in information exchange among consumers (Chan \& Ngai, 2011; Chu \& Kim, 2011; Kim et al., 2014; Kunja \& GVRK, 2018; Richins, 1984). It can significantly affect attitudes and consumer behavior and is also considered as one of the key marketing tools (Avery et al., 1999; Chen \& Xie, 2008). Indeed, this type of communication has been more effective in consumers decision making than other traditional marketing tools, such as personal selling, or advertising media (Engel et al., 1969; Katz \& Lazarfeld, 1955; Lee et al., 2006), because it is considered more credible and reliable than any resource information generated by an institution (Wu \& Wang, 2011). More recently, considering the growth in technology, the advent of the internet has played a significant role in exchange in information transmission. Recent statistics from January 2018 indicate that more than fifty percent or about four billion people in the world are using the internet (Internet World Statistics, 2018); with Europe representing about 11.3 percent of the 
world's internet usage. As a result, the rapid development of the internet can enable sharing of information to a vast amount of people worldwide without limitations (Hennig-Thurau et al., 2004; Reimer $\&$ Benkenstein, 2016). This facilitates a fertile ground for eWOM communication through various virtual platforms on the internet, which enables consumers to share and recommend their opinions about services and products (Cheung \& Lee, 2012; Cheung \& Thadani, 2012). Given the ease of access to the Internet, it provides many opportunities to consumers who rely on eWOM to generate information from other consumers to form opinions about goods and services (Sparks \& Browning, 2011; Zhao \& Xie, 2011). On the other hand, consumers can willingly share or post experiences and rate firms or brands (Yang et al., 2015). Furthermore, eWOM enables consumers to reduce time and effort in order to obtain information about specific products or services (Goldsmith \& Horowitz, 2006). Brand image is important for companies if consumers have a favorable image as it can contribute to an increase in market share, and market success, thus allowing a firm to have a better position in the market (Sondoh et al., 2007). Several studies investigated the relationship between eWOM, purchase intention, and brand image were limited to specific countries and industries, so the previous scholars confirmed to explore this relationship in different context (countries, industries), also the previous studies indicated to study the research model with different potential moderator (Al Halbusi \& Tehseen, 2018; Alam Hamdani \& Abdul Fatah Maulani, 2018; Engel et al., 1969; Kazmi \& Mehmood, 2016; Torlak et al., 2014). For this, few researchers have investigated eWOM communication, while none has looked to examine this research model in a Northern Cyprus context (developing countries). We extended to explore the moderator effect of product type, and focus on how eWOM effects consumers' behavior of Generation Y and $\mathrm{Z}$. The aim of this research observes the effects of eWOM communication on consumers' PI through brand image. For this purpose, we empirically test our research model on consumers' use of smartphone brands in the Turkish Republic of Northern Cyprus. More specifically, the proposed model tests how eWOM affects consumers' behavior to increase purchase.

Our research paper is planned to conduct as follows. First, it provides a discussion about the literature related to eWOM, WOM, BI, PI, product type and the hypothesis of each variable. Secondly, it introduces the research framework. Third, an explanation of the research methods and a discussion of the statistical results are given. Finally, a summary of the findings and a discussion of the research is presented.

\section{Literature review}

\subsection{From Traditional to Electronic WOM}

There are various definitions of traditional WOM which have been defined as "oral, person to person communication between a receiver and a communicator whom the receiver perceives as non-commercial, concerning a brand, a product or a service." (Arndt, 1967). Harrison and Walker (2001) defined it as an "informal person-to-person communication between a perceived non-commercial communicator and a receiver regarding a brand, a product, an organization, or a service." Further, they described WOM as "informal communications directed at other consumers about the ownership, usage, or characteristics of particular goods and services and/or their sellers." (Krishnamurthy \& Kumar, 2018; Litvin et al., 2008; Sirakaya-Turk, Ekinci, \& Martin, 2015; Westbrook, 1987). Additionally, previous research studies have shown that consumers perceive offline WOM as more trustworthy and persuasive than other forms of mass media such as editorial recommendations, newspaper, television or radio advertisements (Steffes \& Burgee, 2009). However, consumers that use WOM communication rely more on this type of communication, due to the reduced perceived risk and uncertainty (Murray, 1991). Thus, offline WOM is more influence than sources of media in playing important roles to motivate consumers to purchase products and services (Herr et al., 1991). Furthermore, the advent of technological development especially the internet has dramatically changed the way consumers communicate thereby transforming traditional WOM into the online WOM (Cheung \& Thadani, 2012). Consequently, the internet has provided several platforms for new types of communication to take place through a variety of forms such as blogs, discussion forums, etc. (Li \& Du, 2011; Weinberg \& Davis, 2005). eWOM has 
obtained more attention from researchers in recent decades (Gruen et al., 2006). Thus, online WOM is deemed more effective than offline WOM due to easily accessible and highly accessible information (Chatterjee, 2001). According to Hennig and Thurau et al. (2004), eWOM can be defined as "any positive or negative statement made by potential, actual or former customers about a product or company that is made available to a multitude of people and institutions via the Internet." eWOM is also facilitated within various types of platforms communicating opinions and exchanging product information which is available to a majority of people and marketers in organizations (Hennig-Thurau et al., 2004). Some researchers are more intention in exploring the motives of consumers for seeking postings through online word of mouth (Goldsmith, 2006; Goldsmith \& Horowitz, 2006; Hennig-Thurau, Walsh, \& Walsh, 2003; Lee et al., 2006). Subramani and Rajagopalan (2003) discussed how electronic word of mouth platforms such as online discussion forums and online communities play a significant role in facilitating influence of products and brands. Furthermore, many empirical studies have examined the impact of eWOM on product purchase (Chevalier \& Mayzlin, 2006; Goldsmith \& Horowitz, 2006) and consumer decisions to purchase (De Bruyn \& Lilien, 2008). An investigation conducted on users of online recommendation indicated online WOM influences product choice (Senecal \& Nantel, 2004). However, eWOM has two kinds of messages for specific groups of people, those who have strong ties such as family and friends or those who have weak ties such as acquaintances leading consumers to post and share product messages. It should be noted that both types of messages provide product, service and experience information and can affect consumers' purchasing intentions and behaviors (Brown \& Reingen, 1987; J.Wang, \& Wang, 2018; Zhao \& Xie, 2011). Furthermore, positive eWOM communications can enhance consumers' attitudes towards a product, service and increase purchase. In contrast, negative eWOM can do serious and sometimes even immutable damage to the firm (Cheung \& Thadani, 2012).

\subsection{EWOM and PI}

eWOM communication messages can reduce the chance of uncertainty for consumers when purchasing brands and products, thus their PI can be more effective (Chatterjee, 2001; Kala \& Chaubey, 2018; Tsimonis \& Dimitriadis, 2014; Wang et al., 2012). At the same time, eWOM messages are deemed a very essential reference as it assists consumers to determine their purchasing decision-making processes (Chan \& Ngai, 2011; Park et al., 2007; Sohaib et al., 2018). Previous studies found a significant positive influence between eWOM and consumers PI (Kunja \& GVRK, 2018) which indicated the effect of eWOM on value co-creation and purchase intention, in that, positive comments, posts, and shares through consumers on social media improve purchase decision making and purchase intention. Reza Jalilvand and Samiei (2012) also studied the significant impact of eWOM communication on purchase intention and brand image. Furthermore, many related studies have examined the influence of eWOM on PI (Evans \& Erkan, 2014; Gabler \& Reynolds, 2013; Kala \& Chaubey, 2018; Torlak et al., 2014; Zhang \& Tran, 2009). Hence, the proposed hypotheses are:

$\mathbf{H}_{1}$ : EWOM communication has a significant influence on purchase intention.

\subsection{EWOM and Brand Image}

A brand has long been deemed a significant concept in marketing activity, thus playing a remarkable role in enabling consumers to identify institutes or industries products and services that lead to differentiating them from other competitors (Keller, 1993, 2009). According to Kotler (1997) "a brand consists of a name, term, sign, or symbol, or any combination of them, that attempts to represent the unique benefits a company can provide to consumers through a particular product or service, in terms of attributes, value, and culture". Consequently, based on brand equity (CBBE) there are two types of brand; awareness, image (Aaker, 1991; Keller, 1993). Thus, brand image is "how a brand is perceived by consumers" (Aaker, 1996). In addition, brand image has been defined "as perceptions about a brand as reflected by the brand associations held in consumer memory"(Keller, 1993). Brand associations reflect the benefit of brands to consumers through linking product and service information to the existing brand in consumers' memories, therefore indicating the product benefits of brands (Keller, 2009). 
Similarly, a brand image plays an important role in contributing to the consumers' decision about a certain brand, thus influencing consumers buying behavior (Johnson \& Puto, 1987).

Bambauer and Mangold (2011) conducted an empirical study on online product reviews in relation to consumer online platforms by examining the effects of eWOM communication on brand equity and purchase intention. Torlak et al. (2014) investigated the effect of word of mouth on purchase intentions and brand image in relation to Turkish cell phone brands. However, Jalilvand and Samiei (2012) also highlighted the influence of eWOM on brand image and PI and found online WOM communication promoted customers purchase intentions in the Iranian automobile industry. Kala and Chaubey (2018) examined the effect of eWOM communication on brand image and purchase intentions, subsequently finding that online WOM enhance consumers' willingness to purchase Indian lifestyle products. According to Sandes and Urdan (2013) experimental study on domestic brands in the Brazilian market, both, either positive or negative online reviews influence the brand image. Furthermore, Farzin and Fattahi (2018) investigated the impact eWOM social network sites had on brand image and purchase intentions; the results indicated that eWOM played a remarkable role in forming a brand image in the minds and memories of consumers; leading to further purchase intention in the context of Iran. Thus, the following hypothesis proposes that:

$\mathbf{H}_{2}$ : EWOM communication has a significant influence on the brand image.

\subsection{Brand Image and Purchase Intention}

Purchase intention has been deemed one of the essential components in consumer buying behavior, as it influences the consumer in making a choice regarding a certain brand among several brands in the market (Spears \& Singh, 2004). Moreover, purchase intention provides the possibility of how determined the consumer is willing to purchase the commodity, the higher possibility purchase suggests a strong purchase intention ( $\mathrm{Wu}, \mathrm{Yeh}, \&$ Hsiao, 2011), also an individual's purchase decision in relation to a certain brand occurs after deep evaluation, thus there are variables that can measure purchase intention to the expectation of the brand to purchase (Moslehpour et al., 2017). Moreover, the study of Kazmi and Mehmood, (2016) examined the effect of electronic word of mouth communication and brand image on purchase in electronic industry related with consumers in Pakistan and the results showed the significant effect for moderator on purchase intention.

According to Jalilvand and Samiei (2012) the effect of eWOM on brand image and PI, indicates that eWOM in online context may improve consumer intention to purchase which promote the association to consumers that desire to purchase for the car industry in Iran. However, Shukla (2010) investigated the influence of interpersonal and brand image and found these can motivate consumers PI, the result indicated the brand image was a significant moderator on luxury purchase intention. Lien et al. (2015) examined the impact of the brand image, direct effect (mediating effect) of online hoteling booking on consumer purchase intention. Similarly, Al Halbusi and Tehseen (2018) investigated the effect of eWOM on brand image and PI on the automobile industry in Malaysia. Hence, the proposed hypothesis is:

H3: Brand image has a significant influence on purchase intention.

\subsection{Product type}

Nelson (1970) categorized products and services as search products and experience products. Search products are products that possess attributes that can be evaluated using external information prior to the purchase or consumption of any kind of product or service. Hence, consumers' abilities rely on previous consumers who used many products before including search goods such as clothing, or house furnishings. In contrast, experience products are products that can be accurately evaluated after the purchased product or product trial. Most personal services include categories such as restaurants food, holidays, travel and hairdressers. Peterson et al. (1997) search product has features that can be measured using available information about a particular product, the internet enables the communication function 
and transactions among consumers generating a more effective communication channel involving the product ensuring that the products are comparable. On the other hand, according to Peterson et al. (1997) experienced product information regarding product attributes and features are not sufficient for consumers to utilize the internet based on communication or transaction. As a result, the consumer who would like to experience the goods prior to purchase or consumption, perceive the internet lacking as a substitute for traditional transaction channels.

Therefore, since consumers' ability uses external information to evaluate search products, information gained from online WOM tends to be more credible for consumers to buy search products. However, before purchasing search products consumers are using online WOM and treat it seriously due to reduced uncertainty, thus online WOM is predictable to be more significant for search products than for experience products. Moreover, consumers need more exterior information on this type of product than for experience products. Consequently, when consumers use eWOM via search products, the results indicate higher perceived usefulness in assisting consumers to understand the features and attributes of a product. Hence, the proposed hypotheses are:

H4: Product type has a significant moderating influence on the relationship between eWOM and purchase intention.

H5: Product type has a significant moderating influence on the relationship between eWOM and brand image.

Fig. 1 shows the structure of the proposed model.

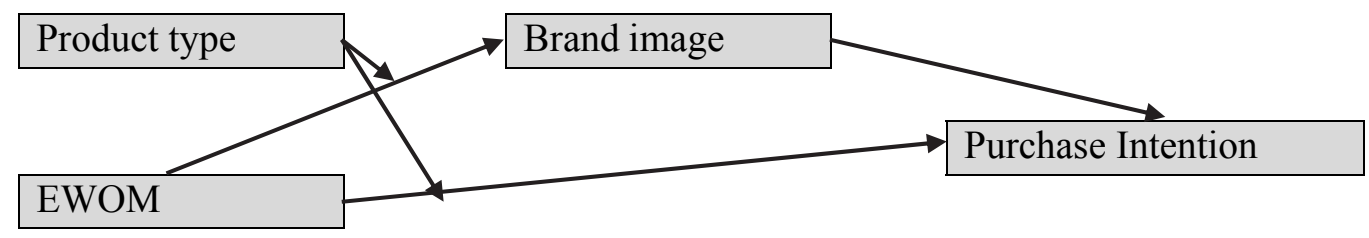

Fig. 1. The structure of the proposed model

\section{Methodology}

\subsection{Population and sampling}

A field study was conducted in the Turkish Republic of Northern Cyprus on all consumers' use of smartphones. The population of this study consisted of all consumers who use smartphones brands, the respondents were chased from Generation $\mathrm{Y}$ and $\mathrm{Z}$. For the differentiation between $\mathrm{Y}$ and $\mathrm{Z}$ we depend on Demographers difference (birth years), so the generation Y (millennial) ranging From 1980 to the end of 1994 and the generation Z (iGen) ranging from 1995 (24 years) to 2001 (18 years). The responses were gathered from customers in the Turkish Republic of Northern Cyprus through a self-administered questionnaire, therefore the questionnaires were distributed based on the non-probability sample technique and purposive sample method was used in order to collect the data.

\subsection{Measurement}

We developed a survey questionnaire using measures based on using a scale adapted from the previous literature reviews. Thus, we modified them slightly to suit our research context. The questionnaire consisted of four parts: eWOM, brand image, PI, and demographical information. The eWOM communication section was measured utilizing six items which were adapted from the study of (Farzin \& Fattahi, 2018). The brand image section was assessed by adopting six items used by Martínez Salinas and Pina Pérez (2009). The six-item scales were used in order to measure purchase intention, which was adapted 
by Farzin and Fattahi (2018) and Reza Jalilvand and Samiei (2012). Finally, the section of the questionnaire collected demographic information from the respondents, such as age, gender, education, and monthly income. All variables of "Electronic word of mouth" "Brand image" and "Purchase intention" were carried out using a five-point Likert-scale, ranging from "strongly disagree" (1) to "strongly agree" (5). Table (1) below presents the research constructs and items used for this study.

\section{Table 1}

The Measurement of Research Constructs

\begin{tabular}{|c|c|}
\hline & Measurement \\
\hline Item & eWOM \\
\hline e-wom1 & $\begin{array}{l}\text { "To make sure that I buy the right products or brands, I often read online reviews of } \\
\text { products and brands written by other fellow members in social networks." }\end{array}$ \\
\hline e-wom2 & $\begin{array}{l}\text { "To choose the right products or brands, I often consult online reviews of products } \\
\text { and brands provided by other fellow members in social networks." }\end{array}$ \\
\hline e-wom3 & $\begin{array}{l}\text { "The information that I spread in social networks regarding the products and brands } \\
\text { usually influences the opinion of other members." }\end{array}$ \\
\hline e-wom4 & $\begin{array}{l}\text { "I always publish my experiences with products and brands on social networks on re- } \\
\text { quest of other members." }\end{array}$ \\
\hline e-wom5 & $\begin{array}{l}\text { "I am willing to share my experiences with products and brands with other fellow } \\
\text { members on social networks." }\end{array}$ \\
\hline \multirow[t]{2}{*}{ e-wom6 } & $\begin{array}{l}\text { "I try to more effectively share my experiences with products and brands with other } \\
\text { fellow members on social networks." }\end{array}$ \\
\hline & Brand image \\
\hline BI1 & "This brand has a high quality. \\
\hline BI2 & This brand has better characteristics than its competitors." \\
\hline BI3 & "This brand has a personality that distinguishes itself from competitors." \\
\hline BI4 & "This brand is a brand that does not disappoint its customers." \\
\hline BI5 & "This brand is one of the best brands in the sector." \\
\hline \multirow[t]{2}{*}{ BI6 } & "This brand is stable in the market." \\
\hline & PI \\
\hline PI1 & "I would buy this product/brand rather than any other brands available." \\
\hline PI2 & "I am willing to recommend others to buy this product/brand." \\
\hline PI3 & "I intend to purchase this product/brand in the future." \\
\hline PI4 & $\begin{array}{l}\text { "I would rather buy the products or brands introduced by my friends on social net- } \\
\text { works than the other existing (competing) products and brands." }\end{array}$ \\
\hline PI5 & $\begin{array}{l}\text { "I would like to recommend the products or brands introduced by my friends on so- } \\
\text { cial networks to other people." }\end{array}$ \\
\hline PI6 & $\begin{array}{l}\text { "I would like to buy the products or brands following their introduction by my friends } \\
\text { on social networks." }\end{array}$ \\
\hline
\end{tabular}

\subsection{Data Collection and Analysis}

Data were collected during the month of August 2018 from consumers who used smartphones in the Turkish Republic of Northern Cyprus. Seven hundred and fifty questionnaires were distributed among the respondents and 402 valid responses were obtained after excluding incomplete questionnaires, the questionnaires rate of response was $56 \%$ from respondents who agreed to participate. In order to analyze the data, we used IBM SPSS version 22.0 for Cronbach's in assessing the scale reliability and descriptive statistics, AMOS version 22.0 for structural equation modeling (SEM) techniques were employed to analyze structural relationships between the variables, latent constructs and test the hypotheses of the research model.

\section{Data Analysis and Results}

\subsection{Confirmatory Factor Analysis: The Measurement Model}

A (CFA) was carried out. The research model measurement for this study meets the required cut-offs of a good model fit: chi-square $(\chi 2 / \mathrm{df})=3.768, \mathrm{CFI}=.976, \mathrm{GFI}=.938, \mathrm{AGFI}=.919$, RMSEA $=.083$, $\mathrm{SRMR}=.040 . \mathrm{PCLOSE}=0.143$, all cut-off values meet recommendations commonly used in literature 
(Gaskin \& Lim, 2016; Hu \& Bentler, 1999). In order to sum up a goodness-of-fit model exists for the overall model measurement (Hair Jr et al., 2010). This accepted benchmark used by recent research (Alzghoul et al., 2018; Elrehail, 2018; Ibrahim \& Aljarah, 2018).

\subsection{Structural Equation Modeling: Hypotheses Testing}

Following a confirmatory factor analysis, the valuation of the structural model through testing of the hypotheses underlying our research model was conducted. The SEM technique was chosen because of the nature of the research model and test hypotheses, and due to the mediating and moderating effects. One of the main reasons SEM was chosen is because of its stringent nature when compared with traditional hierarchical regression analysis (Hair et al., 2010).To adequately test the moderation effect, a bias-corrected bootstrapping (2000 samples) method was chosen, as researchers such as (Preacher \& Hayes, 2004) advocates that the bootstrapping method is a powerful tool for testing indirect effects; due to its ability to resample the dataset in order to create a confidence interval (CI) for moderators (MacKinnon et al., 2002). The relationships between the latent variables indicate that the significance and strength of each of the hypothesized effects developed for this research model accurately, capturing a well model fit for the model. Overall the fitness of a model measurement exceeded the common acceptable level (Bagozzi \& Yi, 1988; Hair et al., 2010). All the research hypotheses with their results illustrated in Table 2, are statistically significant at $\mathrm{P}<0.05$ including direct and interaction effects.

Table 2

Results of the structural model for the direct relationships among constructs

\begin{tabular}{|c|c|c|c|c|c|}
\hline \multicolumn{2}{|c|}{ Hypothesized relationships } & \multirow{2}{*}{$\begin{array}{c}\text { Estimate } \\
0.728\end{array}$} & \multirow{2}{*}{\begin{tabular}{|c|}
$\mathbf{C R}$ \\
0.057
\end{tabular}} & \multirow{2}{*}{$\begin{array}{c}\boldsymbol{P} \\
* * *\end{array}$} & \multirow{2}{*}{$\begin{array}{c}\text { Result } \\
\text { Supported }\end{array}$} \\
\hline H1. eWOM & Purchase intention & & & & \\
\hline H2. eWOM & Brand image & 0.290 & 0.051 & $* * *$ & Supported \\
\hline H3. Brand image & Purchase intention & 0.007 & 0.054 & 0.895 & Not Supported \\
\hline Age & Purchase intention & -0.090 & 0.039 & 0.020 & Control \\
\hline Gander & Purchase intention & 0.035 & 0.521 & 0.602 & Control \\
\hline \multicolumn{6}{|c|}{ Interaction effect } \\
\hline H4. eWOM_X_Proudet type & Purhces intention & 0.095 & 1.890 & 0.059 & Supported \\
\hline H5. eWOM_X_Proudet type & Brand image & 0.051 & 1.124 & 0.895 & Not Supported \\
\hline
\end{tabular}

\subsubsection{Direct effects}

Table 2 and Fig. 2 present the results; the individual tests of significance of the relationship between the variables. It reveals that, as expected eWOM has a significant influence on purchase intention $(\beta=$ $0.728, \mathrm{p}<0.001)$. Therefore, (H1) is supported. This finding is consistent with the result of Jalilvand $\&$ Samiei (2012), conducted in Iran in relation to the automobile industry which indicated that eWOM had a significant effect on PI.

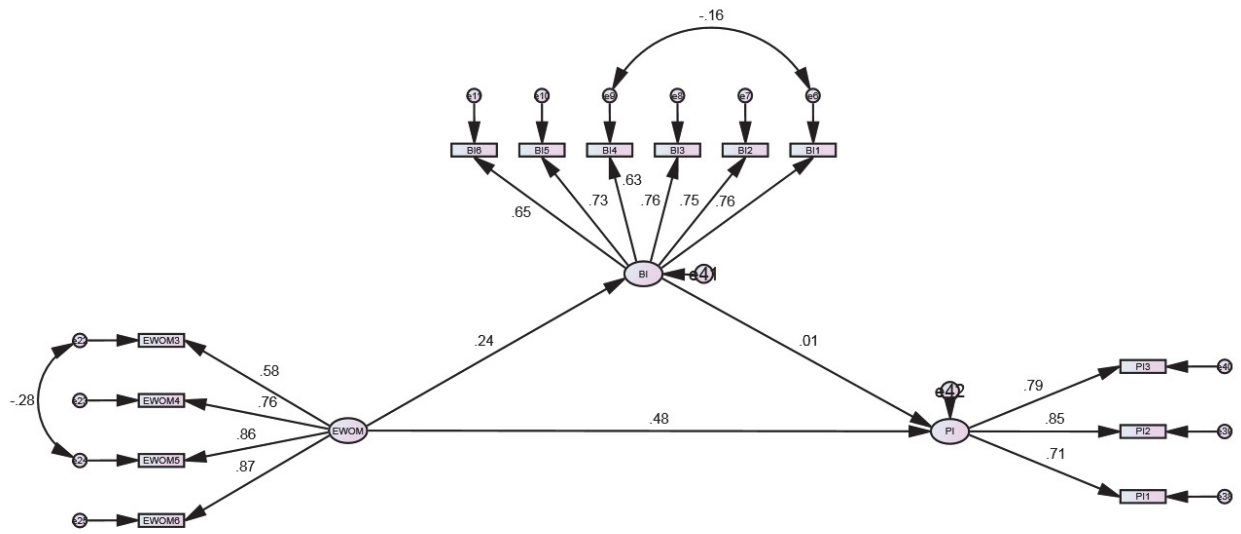

Fig. 2. Structural Model 
The result shows that $\mathrm{H}_{2}(\beta=0.290, \mathrm{p}<0.001)$ is supported, as it predicts that eWOM has a positive direct effect on brand image. That result is inconsistent with Kazmi and Mehmood (2016) who stated that eWOM has a significant effect on brand image. The researchers conducted their study in the region of Haripur and found that eWOM has a significant effect on BI. Moreover, pertaining to H3; it was found not to be supported, as it indicated a negative impact of the brand image on PI $(\beta=0.007, p<$ 0.895). However, the brand image does not considerably influence the smartphone user's intention to purchase. Hence, for the moderation effect of $\mathrm{H}_{4}$, the result showed that product type strengthens the positive relationship between eWOM and purchase intention $(\beta=0.095, \mathrm{p}<0.059)$. Therefore, $\mathrm{H}_{4}$ is supported. The result of $\mathrm{H}_{5}$ show that there is no moderating effect of product type in the relationship between eWOM and brand image $(\beta=0.051, \mathrm{p}<0.895)$. Therefore, $\mathrm{H}_{5}$ is not supported. Table 2 explains the interaction effect of product type on the linkage between eWOM and BI, illustrated that reduced product types of mobile smartphones available on the market enhance customer purchase intention. Therefore, these variables play a significant role on the development and enhancement of electronic purchase intention. Furthermore, Table 2 show that the control variable (Age) has a significant impact on PI. In constrict, (Gender) has an insignificant impact on PI.

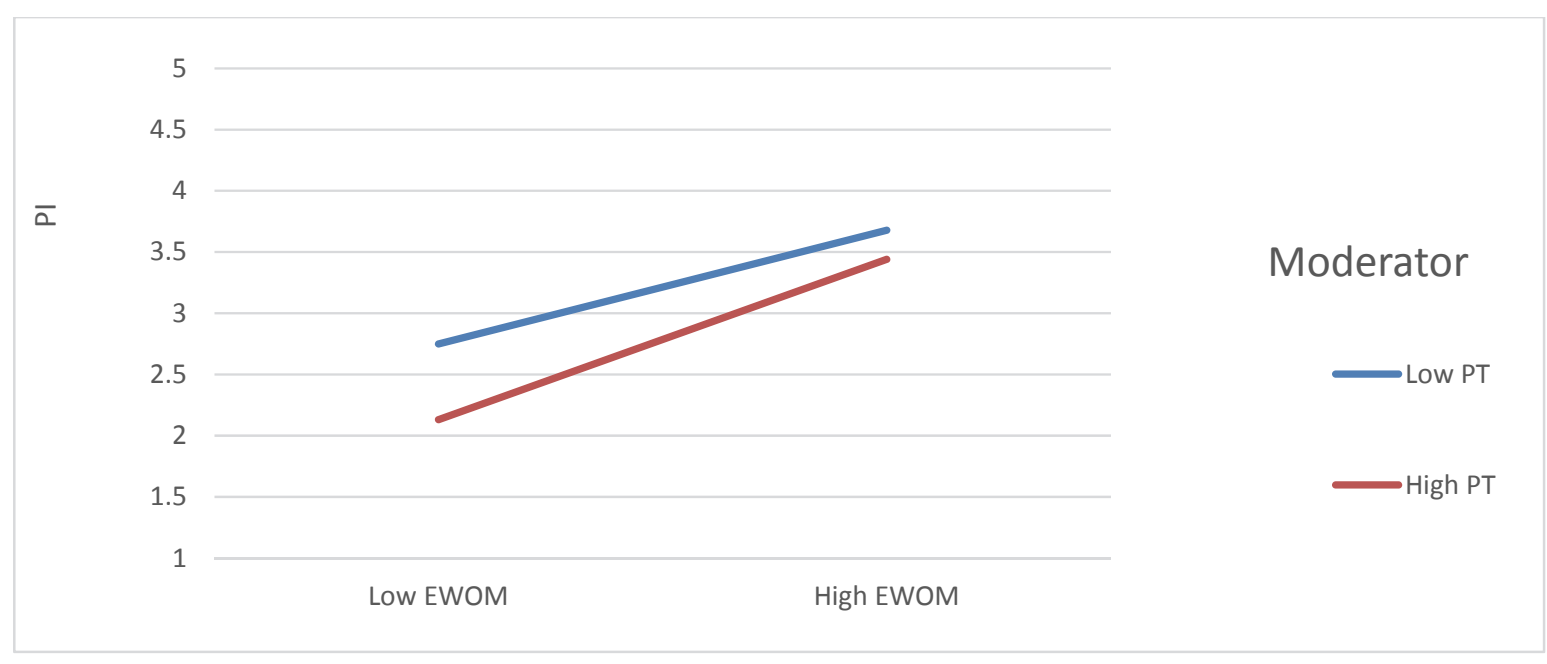

Note: PI Purchase intention; EWOM: electronic word of mouth; PT: product type

Fig. 3. Moderating impact of product type between EWOM and purchase intention

\subsection{Further analysis: mediating effect}

In order to test the mediating effects, this study employed the bootstrapping procedure and identified whether the direct relationship of eWOM and purchase intention through brand image is statistically significant. The direct effect results (Table 2) confirm that the direct effect between eWOM and purchase intention is statistically significant. In other words, when the researchers want to test the mediation effect, they should first test the main effect between the independent variable and dependent variable (Awang, 2015; Baron \& Kenny, 1986). When the mediator impact of the brand image is included in the research model, the direct effect between eWOM and purchase intention would change. If the direct impact diminishes but remains statistically significant, the mediation effects in this situation are called "partial mediation". However, if the direct effect diminishes but becomes statistically insignificant, then the mediation effect in this situation is known as "full mediation" (Awang, 2015). Table 3 reveals a statistically insignificant indirect impact of eWOM on PI via BI. However, eWOM has a negative direct effect on PI when BI was entered as a mediator effect.

\section{Table 3}

Results of the structural model for the indirect relationships among constructs

\begin{tabular}{llcccccc} 
Hypothesized path & & Estimate & Lower & Upper & P & Result \\
eWOM $\rightarrow \quad$ BI $\rightarrow$ & PI & 0.002 & -0.023 & 0.026 & 0.892 & Not Supported \\
\hline Note: EWOM: electronic word of mouth; BI: brand image; PI: purchase intention & &
\end{tabular}


The results of the mediation effect indicate that there is no mediation effect of the brand image between the relationship of eWOM and PI.

Table 4

Results of the structural model for the correlations between eWOM, BI and PI

\begin{tabular}{cccccc}
\hline & Mean & Std. Deviation & EWOM & BI & PI \\
\hline eWOM & 2.013 & 0.577 & 1 & & \\
BI & 3.557 & 0.610 & $0.274^{* *}$ & 1 & \\
PI & 2.744 & 0.760 & $0.546^{* *}$ & $0.158^{* *}$ & 1 \\
\hline
\end{tabular}

Table 4 presented the findings of individual tests of significance of the relationship between the variables. At a significant level of 0.01 , person correlation for all relationships was found significant. Person correlation for eWOM and PI is $0.546^{* *}$ found significant relationships, the correlation for BI and PI is $0.158^{* *}$ and correlation for Ewom and $\mathrm{BI}$ is $0.274^{* *}$.

\section{Discussion}

The internet has opened a new arena for eWOM especially, regarding the ability it has to spread information related to products among consumers within the network thus reaching a wide variety of potential consumers. Therefore, the internet can facilitate eWOM among consumers. With the global growth of eWOM especially in Northern Cyprus, researchers and marketers are trying to better understand how eWOM can influence consumer behavior and consumer's willingness to purchase. The purpose of this study was to explore the possible influence of eWOM on purchase intention through brand image in the smartphone industry. It has been remarked that consumers who feel uncertainty towards a certain brand tend to search for online reviews and recommendations for that brand. Searching for online information and reviews are useful for the consumer in making an informed and confident purchase decision. Therefore, persuasive and prior consumer recommendations and reviews have a strong positive influence on intention to purchase. The findings have revealed the significant impact of eWOM on purchase intention, including the obtain information and reviews /recommendations regarding brands from eWOM channels and, use of information to purchase certain products or brands. Thus, our results are in line with prior studies which found eWOM communication to be a significant factor affecting consumer intention to purchase (Kazmi \& Mehmood, 2016; Reza Jalilvand \& Samiei, 2012; Torlak et al., 2014). The findings indicate that eWOM communication is formed through appropriate reviews/recommendations from those who had previous experience concerning the product or brand leading to consumer intention to purchase. On another hand, our results show from this study that brand image does not have a significant effect on consumer intention to purchase. This result is contrary to the results of other studies (e.g. Kazmi \& Mehmood, 2016; Jalilvand \& Samiei, 2012) from research conducted in Iran and Pakistan, respectively. Thus, the effect of eWOM communication is more significant in terms of consumer intention to purchase compared with the brand image. Additionally, eWOM communication highlighted the role of eWOM in persuading consumers to purchase certain products or brands. From the results, we can observe that the influence of eWOM on PI cannot mediate the brand image, in the context smartphone brand in Northern Cyprus. Therefore, the result of the study also illustrates the effect of product type among eWOM on PI, indicating the significant effect of product type between eWOM on consumer PI. The finding indicates that eWOM on purchase intention can moderate product type. In contrast, our results show the effect of product type between eWOM and the brand image does not significantly affect eWOM and brand image. Thus, indicating eWOM and brand image do not moderate product type. Ultimately, the link among brand image and purchase intention indicate that usage of community tools is growing among Cypriot consumers, however, these are not enough to influence consumer purchase decisions. This indicates that online information and reviews do not motivate consumers in relation to brands or products. This finding can assist marketers in building an appropriate image of the brand which leads to a positive image from a consumer perspective. Consequently, consumers are receiving positive reviews from previous consumers toward the brand. 


\section{Conclusion}

WOM is deemed one of the most important channels of communication to exchange information between consumers which affects consumer's behavior. With the advent of the internet and increasing usage of internet technologies, consumers have dramatically moved towards online commutation channels to obtain information related to products and services to finalize purchase decisions. eWOM plays a significant role in creating a positive image of the firms and brands and can also impact consumers' intention to purchase. On the other hand, it allows for a reduction in expenditure for firms such as promotion in the traditional media. Moreover, the internet has facilitated the use of eWOM in generating both recommenders and reviewers who have previous experience in relation to the brand and this can be employed as a strategic communication network. Consumers' opinions and reviews can influence other consumers purchase decisions. Marketers should attempt to be attentive to the potential of this method, as they can influence this form of computation tool. Therefore, marketers can create plat-

form applications to interact with customers and potential consumers and enhance the image of the brand from the perspective of customers. Ultimately, firms and marketers must concentrate on online communication channels to affect consumers' intention toward purchasing brands and brand image.

\section{Future research}

There are some limitations for this study, for instance, the population sample just focused on the user of smartphone and did not include the other context. In addition, the sample of research examined in northern Cyprus context and the majority of respondents were from younger groups. Our study context may limit the generalizability of our findings. The type of sampling was a non -probability sample because the sample chosen depended on the objective of study and the population of study had specific characteristics and limited to smartphone brand users. Thus, we chose purposive sample and this may limit the generalizability of our findings. Future study for the current study model can be extended in a different context, countries (i.e. developed, emerging, developing, industries (i.e. e-commerce, tourism) and explore the current model in social media platforms sites (i.e. Facebook, Twitter), and demographics, international, culture (i.e. collectivism versus individualism). Future study can also be extended in a new comparative study between countries, industries, social media sites eWOM provider and can focus on the relationship between eWOM and different variables such as brand personality, dimensions of the brand image (functional, experiential, attitudinal).

\section{References}

Aaker, D. A. (1991). Managing brand equity : capitalizing on the value of a brand name. Free Press. Aaker, D. A. (1996). Building strong brands. Free Press.

Al Halbusi, H., \& Tehseen, S. (2018). The Effect of Electronic Word-Of-Mouth (EWOM) On Brand Im-age and Purchase Intention: A Conceptual Paper. SocioEconomic Challenges, 2.

Alam Hamdani, N., \& Abdul Fatah Maulani, G. (2018). The influence of E-WOM on purchase intentions in local culinary business sector. International Journal of Engineering \& Technology, 7(2.29), 246.

Alzghoul, A., Elrehail, H., Emeagwali, O. L., \& AlShboul, M. K. (2018). Knowledge management, workplace climate, creativity and performance. Journal of Workplace Learning, 30(8), 592-612.

Arndt, J. (1967). Role of Product-Related Conversations in the Diffusion of a New Product. Journal of Marketing Research, 4(3), 291.

Avery, C., Resnick, P., \& Zeckhauser, R. (1999). The Market for Evaluations. American Economic Review, 89(3), 564-584.

Awang, Z. (2015). SEM made simple: A gentle approach to learning Structural Equation Modeling. MPWS Rich Publication.

Bagozzi, R. P., \& Yi, Y. (1988). On the evaluation of structural equation models. Journal of the Academy of Marketing Science, 16(1), 74-94.

Bambauer-Sachse, S., \& Mangold, S. (2011). Brand equity dilution through negative online word-ofmouth communication. Journal of Retailing and Consumer Services, 18(1), 38-45. 
Baron, R. M., \& Kenny, D. A. (1986). The moderator-mediator variable distinction in social psychological research: Conceptual, strategic, and statistical considerations. Journal of Personality and Social Psychology, 51(6), 1173-1182.

Brown, J. J., \& Reingen, P. H. (1987). Social Ties and Word-of-Mouth Referral Behavior. Journal of Consumer Research, 14(3), 350.

Chan, Y. Y. Y., \& Ngai, E. W. T. (2011). Conceptualising electronic word of mouth activity. Marketing Intelligence \& Planning, 29(5), 488-516.

Chatterjee, P. (2001). Online Reviews: Do Consumers Use Them? ACR North American Advances, $N A-28,129-133$.

Chen, Y., \& Xie, J. (2008). Online Consumer Review: Word-of-Mouth as a New Element of Marketing Communication Mix. Management Science, 54(3), 477-491.

Cheung, C. M. K., \& Lee, M. K. O. (2012). What drives consumers to spread electronic word of mouth in online consumer-opinion platforms. Decision Support Systems, 53(1), 218-225.

Cheung, C. M. K., \& Thadani, D. R. (2012). The impact of electronic word-of-mouth communication: A literature analysis and integrative model. Decision Support Systems, 54(1), 461-470.

Chevalier, J. A., \& Mayzlin, D. (2006). The Effect of Word of Mouth on Sales: Online Book Reviews. Journal of Marketing Research, 43(3), 345-354.

Chu, S.-C., \& Kim, Y. (2011). Determinants of consumer engagement in electronic word-of-mouth (eWOM) in social networking sites. International Journal of Advertising, 30(1), 47-75.

De Bruyn, A., \& Lilien, G. L. (2008). A multi-stage model of word-of-mouth influence through viral marketing. International Journal of Research in Marketing, 25(3), 151-163.

Elrehail, H. (2018). The relationship among leadership, innovation and knowledge sharing: A guidance for analysis. Data in Brief, 19, 128-133.

Engel, J. ., Blackwell, R. ., \& Kegerreis, R. . (1969). How information is used to adopt and innovation. Journal of Advertising Research, 9 ., 3-8.

Evans, C., \& Erkan, I. (2014). The impacts of electronic word of mouth in social media on consumers` purchase intentions. International Conference on Digital Marketing (ICODM2014).

Farzin, M., \& Fattahi, M. (2018). eWOM through social networking sites and impact on purchase intention and brand image in Iran. Journal of Advances in Management Research, 15(2), 161-183.

Gabler, C. B., \& Reynolds, K. E. (2013). Buy Now or Buy Later: The Effects of Scarcity and Discounts on Purchase Decisions. Journal of Marketing Theory and Practice, 21(4), 441-456.

Gaskin, J., \& Lim, J. (2016). Model fit measures.

Goldsmith, R. E. (2006). Electronic Word-of-Mouth. In Electronic Commerce (pp. 408-412). IGI Global.

Goldsmith, R. E., \& Horowitz, D. (2006). Measuring Motivations for Online Opinion Seeking. Journal of Interactive Advertising, 6(2), 2-14.

Gruen, T. W., Osmonbekov, T., \& Czaplewski, A. J. (2006). eWOM: The impact of customer-tocustomer online know-how exchange on customer value and loyalty. Journal of Business Research, 59(4), 449-456.

Hair Jr, J. F., Black, W. C., Babin, B. J., \& Anderson, R. E. (2010). Multivariate Data Analysis.

Harrison-Walker, L. J. (2001). The measurement of word-of-mouth communication and an investigation of service quality and customer commitment as potential antecedents. Journal of Service Research, 4(1), 60-75.

Hennig-Thurau, T., Gwinner, K. P., Walsh, G., \& Gremler, D. D. (2004). Electronic word-of-mouth via consumer-opinion platforms: What motivates consumers to articulate themselves on the Internet? Journal of Interactive Marketing, 18(1), 38-52.

Hennig-Thurau, T., Walsh, G., \& Walsh, G. (2003). Electronic Word-of-Mouth: Motives for and Consequences of Reading Customer Articulations on the Internet. International Journal of Electronic Commerce, 8(2), 51-74.

Herr, P. M., Kardes, F. R., \& Kim, J. (1991). Effects of Word-of-Mouth and Product-Attribute Information on Persuasion: An Accessibility-Diagnosticity Perspective. Journal of Consumer Research, 17(4), 454. 
Hu, L., \& Bentler, P. M. (1999). Cutoff criteria for fit indexes in covariance structure analysis: conventional criteria versus new alternatives. Structural Equation Modeling: A Multidisciplinary Journal, 6(1), 1-55.

Ibrahim, B., \& Aljarah, A. (2018). Dataset of relationships among social media marketing activities, brand loyalty, revisit intention. Evidence from the hospitality industry in Northern Cyprus. Data in Brief, 21, 1823-1828.

Johnson, M., \& Puto, C. (1987). A Review of Consumer Judgment and Choice. Articles and Chapters.

Kala, D., \& Chaubey, D. S. (2018). The effect of eWOM communication on brand image and purchase intention towards lifestyle products in India. International Journal of Services, Economics and Management, 9(2), 143-157.

Katz, E., \& Lazarfeld, P. . (1955). Personal Influence. Free Press.

Kazmi, A., \& Mehmood, Q. S. (2016). The effect of electronic word of mouth communication and brand image on purchase intention: A case of consumer electronics in Haripur, Pakistan. Management Science Letters, 409-508.

Keller, K. L. (1993). Conceptualizing, Measuring, and Managing Customer-Based Brand Equity. Journal of Marketing, 57(1), 1.

Keller, K. L. (2009). Managing the growth tradeoff: Challenges and opportunities in luxury branding. Journal of Brand Management, 16(5-6), 290-301.

Kim, E., Sung, Y., \& Kang, H. (2014). Brand followers' retweeting behavior on Twitter: How brand relationships influence brand electronic word-of-mouth. Computers in Human Behavior, 37, 18-25.

Kotler, P. (1997). Marketing management (7th ed.). Upper Saddle River.

Krishnamurthy, A., \& Kumar, S. R. (2018). Electronic word-of-mouth and the brand image: Exploring the moderating role of involvement through a consumer expectations lens. Journal of Retailing and Consumer Services, 43(October 2017), 149-156.

Kunja, S. R., \& GVRK, A. (2018). Examining the effect of eWOM on the customer purchase intention through value co-creation (VCC) in social networking sites (SNSs). Management Research Review, MRR-04-2017-0128.

Lee, M. K. O., Cheung, C. M. K., Lim, K. H., \& Ling Sia, C. (2006). Understanding customer knowledge sharing in web-based discussion boards. Internet Research, 16(3), 289-303.

Li, F., \& Du, T. C. (2011). Who is talking? An ontology-based opinion leader identification framework for word-of-mouth marketing in online social blogs. Decision Support Systems, 51(1), 190-197.

Lien, C.-H., Wen, M.-J., Huang, L.-C., \& Wu, K.-L. (2015). Online hotel booking: The effects of brand image, price, trust and value on purchase intentions. Asia Pacific Management Review, 20(4), 210 218.

Litvin, S. W., Goldsmith, R. E., \& Pan, B. (2008). Electronic word-of-mouth in hospitality and tourism management. Tourism Management, 29(3), 458-468.

MacKinnon, D. P., Lockwood, C. M., Hoffman, J. M., West, S. G., \& Sheets, V. (2002). A comparison of methods to test mediation and other intervening variable effects. Psychological Methods, 7(1), 83-104.

Martínez Salinas, E., \& Pina Pérez, J. M. (2009). Modeling the brand extensions' influence on brand image. Journal of Business Research, 62(1), 50-60.

Moslehpour, M., Wong, W.-K., Lin, Y. H., \& Le Huyen Nguyen, T. (2017). Top purchase intention priorities of Vietnamese low cost carrier passengers: expectations and satisfaction. Eurasian Business Review, 8(4), 371-389.

Murray, K. B. (1991). A Test of Services Marketing Theory: Consumer Information Acquisition Activities. Journal of Marketing, 55(1), 10.

Nelson, P. (1970). Information and Consumer Behavior. Journal of Political Economy, 78(2), 311329.

Park, D.-H., Lee, J., \& Han, I. (2007). The Effect of On-Line Consumer Reviews on Consumer Purchasing Intention: The Moderating Role of Involvement. International Journal of Electronic Commerce, 11(4), 125-148. 
Peterson, R. A., Balasubramanian, S., \& Bronnenberg, B. J. (1997). Exploring the Implications of the Internet for Consumer Marketing. Journal of the Academy of Marketing Science, 25(4), 329-346.

Preacher, K. J., \& Hayes, A. F. (2004). SPSS and SAS procedures for estimating indirect effects in simple mediation models. Behavior Research Methods, Instruments, \& Computers, 36(4), 717-731.

Reimer, T., \& Benkenstein, M. (2016). Altruistic eWOM marketing: More than an alternative to monetary incentives. Journal of Retailing and Consumer Services, 31, 323-333.

Reza Jalilvand, M., \& Samiei, N. (2012). The effect of electronic word of mouth on brand image and purchase intention. Marketing Intelligence \& Planning, 30(4), 460-476.

Richins, M. L. (1984). Word of Mouth Communication As Negative Information. ACR North American Advances, NA-11.

Sandes, F. S., \& Urdan, A. T. (2013). Electronic Word-of-Mouth Impacts on Consumer Behavior: Exploratory and Experimental Studies. Journal of International Consumer Marketing, 25(3), 181197.

Senecal, S., \& Nantel, J. (2004). The influence of online product recommendations on consumers' online choices. Journal of Retailing, 80, 159-169.

Shukla, P. (2010). Impact of interpersonal influences, brand origin and brand image on luxury purchase intentions: Measuring interfunctional interactions and a cross-national comparison. Journal of World Business, 46(2), 242-252.

Sirakaya-Turk, E., Ekinci, Y., \& Martin, D. (2015). The efficacy of shopping value in predicting destination loyalty. Journal of Business Research, 68(9), 1878-1885.

Sohaib, M., Hui, P., \& Akram, U. (2018). Impact of eWOM and risk-taking in gender on purchase intentions: evidence from Chinese social media. International Journal of Information Systems and Change Management, 10(2), 101.

Sondoh, S. L., Wan Omar, M., Wahid, N. A., Ismail, I., \& Harun, A. (2007). The effect of brand image on overall satisfaction and loyalty intention in the context of color cosmetic. Asian Academy of Management Journal, 12(1), 83-107.

Sparks, B. A., \& Browning, V. (2011). The impact of online reviews on hotel booking intentions and perception of trust. Tourism Management, 32(6), 1310-1323.

Spears, N., \& Singh, S. N. (2004). Measuring Attitude toward the Brand and Purchase Intentions. Journal of Current Issues \& Research in Advertising, 26(2), 53-66.

Steffes, E. M., \& Burgee, L. E. (2009). Social ties and online word of mouth. Internet Research, 19(1), $42-59$.

Subramani, M. R., \& Rajagopalan, B. (2003). Knowledge-sharing and influence in online social networks via viral marketing. Communications of the ACM, 46(12), 300.

Torlak, O., Yalin Ozkara, B., Ali Tiltay, M., Cengiz, H., \& Fatih Dulger, M. (2014). The Effect of Electronic Word of Mouth on Brand Image and Purchase Intention: An Application Concerning Cell Phone Brands for Youth Consumers in Turkey.

Tsimonis, G., \& Dimitriadis, S. (2014). Brand strategies in social media. Marketing Intelligence \& Planning, 32(3), 328-344.

Wang, J. J., Wang, L. Y., \& Wang, M. M. (2018). Understanding the effects of eWOM social ties on purchase intentions: A moderated mediation investigation. Electronic Commerce Research and Applications, 28, 54-62.

Wang, X., Yu, C., \& Wei, Y. (2012). Social Media Peer Communication and Impacts on Purchase Intentions: A Consumer Socialization Framework. Journal of Interactive Marketing, 26(4), 198208.

Weinberg, B. D., \& Davis, L. (2005). Exploring the WOW in online-auction feedback. Journal of Business Research, 58(11), 1609-1621.

Westbrook, R. A. (1987). Product/Consumption-Based Affective Responses and Postpurchase Processes. Journal of Marketing Research, 24(3), 258.

Wu, P. C. S., \& Wang, Y. (2011). The influences of electronic word-of-mouth message appeal and message source credibility on brand attitude. Asia Pacific Journal of Marketing and Logistics, 23(4), $448-472$. 
Wu, P. C. S., Yeh, G. Y.-Y., \& Hsiao, C.-R. (2011). The effect of store image and service quality on brand image and purchase intention for private label brands. Australasian Marketing Journal (AMJ), 19(1), 30-39.

Yang, L., Cheng, Q., \& Tong, S. (2015). Empirical study of eWOM's influence on consumers' purchase decisions. The Strategies of China's Firms, 123-135.

Zhang, R., \& Tran, T. T. (2009). Helping E-Commerce Consumers Make Good Purchase Decisions: A User Reviews-Based Approach (pp. 1-11). Springer, Berlin, Heidelberg.

Zhao, M., \& Xie, J. (2011). Effects of Social and Temporal Distance on Consumers' Responses to Peer Recommendations. Journal of Marketing Research, 48(3), 486-496.

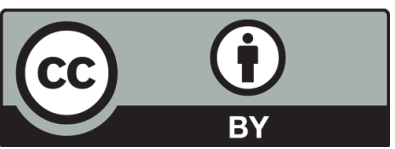

(C) 2019 by the authors; licensee Growing Science, Canada. This is an open access article distributed under the terms and conditions of the Creative Commons Attribution (CC-BY) license (http://creativecommons.org/licenses/by/4.0/). 